\title{
Upaya Pengembangan Pendidikan Anak Melalui Kegiatan Rumah Pintar Di Desa Sungai Mawang Kabupaten Sanggau
}

\author{
Siti Ardiyanti ${ }^{*}$, Marlenywati ${ }^{1}$, Hanum Mukti Rahayu ${ }^{1}$ \\ ${ }^{1}$ Universitas Muhammadiyah Pontianak, Kalimantan Barat, Indonesia \\ *Email: sitiardiyanti.ipa1@,gmail.com
}

\begin{abstract}
Abstrak
Desa Sungai Mawang merupakan salah satu desa yang ada di kabupaten sanggau, desa tersebut termasuk ke dalam kategori daerah tertinggal. Dalam bidang pendidikan, di Desa Sungai Mawang masih banyak masyarakat yang berpendidikan rendah atau hanya bersekolah kurang dari 9 tahun, bahkan buta huruf. Selain itu, sekolah pendidikan anak usia dini (PAUD) yang tersedia belum dapat dimaksimalkan untuk mengembangkan pendidikan dasar pada anak usia dini atau bahkan belum tersedia pada setiap dusun. Padahal pendidikan merupakan salah satu aspek terpenting yang menjadi tolak ukur serta sebagai sarana untuk meningkatkan kualitas sumber daya manusia. Dengan demikian perlu adanya pemberdayaan bagi masyarakat melalui kegiatan rumah pintar yang dilakukan utuk menuntaskan semua masalah tersebut. Tujuan penulisan ini adalah ingin mendeskripsikan kegiatan rumah pintar Desa Sungai Mawang sebagai sarana belajar anak serta masyarakat Desa Sungai Mawang kabupaten Sanggau. Metode pelaksanaan kegiatan rumah pintar dilakukan melalui tahapan persiapan, pelaksanaan dan evaluasi. Hadirnya rumah pintar sebagai salah satu upaya pemberdayaan masyarakat di sektor pendidikan sangatlah penting. Paling tidak dapat memberikan kesempatan pada masyarakat yang tidak tersentuh oleh pendidikan formal untuk dapat merasakan pendidikan di rumah pintar ini. Sistem penyelenggaraan rumah pintar mengacu pada kondisi, situasi dan kemampuan masyarakat di Desa tersebut dengan tetap berorientasi pada pemberdayaan masyarakat agar masyarakat khususnya anak-anak bisa belajar, menambah pengalaman dan keterampilan yang akan berguna bagi kehidupannya.
\end{abstract}

Kata kunci: Rumah Pintar, Desa Sungai Mawang, Pemberdayaan Masyarakat, Pendidikan

\begin{abstract}
Sungai Mawang village is one of the villages in Sanggau district, the village belongs to the category of underdeveloped regions. In the education sector, there are still many people in Sungai Mawang Village who have low education or only school for less than 9 years, even illiterate. In addition, the early childhood education (PAUD) available cannot be maximized to develop basic education in early childhood or even not yet available in every hamlet. Even though education is one of the most important aspects that becomes a benchmark and as a means to improve the quality of human resources. Thus the need for empowerment for the community through smart home activities carried out to complete all these problems. The purpose of this paper is to describe the smart house activities of Sungai Mawang Village as a learning tool for children and the people of the Sungai Mawang Village in Sanggau district. The method of implementing smart home activities is carried out through the stages of preparation, implementation and evaluation. The presence of smart homes as an effort to empower the community in the education sector is very important. At least it can provide opportunities for people who are not touched by formal education to be able to experience education in this smart home. The smart home management system refers to the conditions, situations and capabilities of the community in the village while being oriented towards community empowerment so that the community, especially children can learn, add experience and skills that will be useful for their lives.
\end{abstract}

Keywords: Smart House, Sungai Mawang Village, Community Empowerment, Education 
Format Sitasi: Ardiyanti S, Marlenywati \& Rahayu H. (2019). Upaya Pengembangan Pendidikan Anak Melalui Kegiatan Rumah Pintar di Desa Sungai Mawang Kabupaten Sanggau. Jurnal Solma, 08(1), 05-13. Doi: http://dx.doi.org/10.29405/solma.v8i1.3012

Diterima: 02 Februari 2019 | Revisi: 04 April 2019 | Dipublikasikan: 30 April 2019.

\section{PENDAHULUAN}

Salah satu modal pembangunan disamping sumber daya alam yang mencukupi adalah kualitas sumber daya manusia. IPM Indonesia berdasarkan Laporan UNDP Tahun 2016 berada di peringkat 113 dari 188 negara dan termasuk kategori pembangunan manusia menengah. Tahun 2016 seperti yang dikutip Harian Tribun Pontianak, Kalimantan Barat menempati urutan IPM ke-29 dari 33 provinsi yang ada di Indonesia, sedangkan Kabupaten Sanggau menempati urutan ke-12 dari 14 kabupaten/kota yang ada di Provinsi Kalimantan Barat. Urutan tersebut menempatkan kategori pembangunan di Kabupaten Sanggau termasuk kedalam kategori rendah dan perlu perhatian dari semua pihak baik pemerintah maupun masyarakat untuk lebih memperhatikan lagi masalah pembangunan di semua sektor. Komponen penilaian pembanguan suatu daerah atau negara dilihat dari indikator Indeks Pembangunan Masyarakat (IPM) mencakup 3 aspek penting yang salah satunya tentang pendidikan (lama rata-rata bersekolah dan tingkat pendidikan) (UNDP, 2016)

Perkembangan teknologi yang terjadi sangat pesat berdampak pada kehidupan manusia (Amirullah \& Susilo, 2018). Oleh sebab itu tingkat Pendidikan masyarakat harus selalu diupayakan. Minimnya tingkat pendidikan di masyarakat menjadi salah satu faktor rendahnya tingkat IPM di kabupaten sanggau. Hal ini dapat dilihat dari data BPS tahun 2015, yaitu banyaknya jumlah masyarakat yang tidak mengenyam pendidikan bangku sekolah sebanyak 44. 194 ataupun yang hanya tamatan sekolah dasar (SD) sebanyak 82.792. (Badan Pusat Statistik, 2017)

Desa Sungai Mawang merupakan salah satu desa yang ada di kabupaten sanggau yang menjadi sasaran dari program KKN-PPM dimana desa tersebut termasuk ke dalam kategori daerah tertinggal. Akses ke lokasi desa tersebut belum semuanya jalan beraspal meskipun dapat ditempuh oleh kendaraan roda 2 atau empat. Sedangkan jika dijangkau dari ibukota Kabupaten Sanggau maka dapat ditempuh selama 1 - 1,5 jam. Dalam bidang pendidikan, di Desa Sungai Mawang masih banyak masyarakat yang berpendidikan rendah atau hanya bersekolah kurang dari 9 tahun, bahkan buta huruf. Hal ini terlihat dengan ratarata pendidikan masyarakat yang lebih banyak tamat SMP dan tidak menamatkan 
sekolahnya. Selain itu, sekolah pendidikan anak usia dini (PAUD) yang tersedia belum dapat dimaksimalkan untuk mengembangkan pendidikan dasar pada anak usia dini atau bahkan belum tersedia pada setiap dusun (Khan, 2016)

Padahal pendidikan merupakan salah satu aspek terpenting yang menjadi tolak ukur serta sebagai sarana untuk meningkatkan kualitas sumber daya manusia (Sulastri, Akbar, Safahi, \& Susilo, 2018; Syintia, Akbar, Safahi, \& Susilo, 2018). Sehubungan dengan pengembangan sumber daya manusia untuk peningkatan kualitas pendidikan. (Kartadinata, 2007) mengemukakan bahwa "Pengembangan sumber daya manusia yang berkualitas adalah proses kontekstual, sehingga pengembangan sumber daya manusia melalui upaya pendidikan bukanlah sebatas menyiapkan manusia yang menguasai pengetahuan dan keterampilan yang cocok dengan dunia kerja saat ini, melainkan juga manusia yang mampu, mau dan siap untuk belajar sepanjang hayat" (Hasiani, 2015).

Pengembangan sumber daya manusia merupakan faktor kunci kesuksesan pembangunan suatu bangsa, karena itu berbagai upaya pengembangan sumber daya manusia haruslah merupakan suatu proses yang berkesinambungan sejak usia dini. Perlu dipahami bahwa anak memiliki potensi untuk menjadi lebih baik di masa mendatang, Namun potensi tersebut hanya dapat berkembang manakala diberi rangsangan, bimbingan, bantuan dan perlakuan yang sesuai dengan tingkat pertumbuhan dan perkembangannya (Khan, 2016). Salah satu aspek yang harus dikembangkan pada anak adalah aspek kognitif. Usaha untuk menggali kemampuan kognitif yang dimiliki oleh anak dapat dilakukan dengan berbagai (Khan, 2016) cara termasuk melalui kegiatan rumah pintar Desa Sungai Mawang untuk dapat membentuk sikap logis, kritis, cermat dan kreatif pada diri anak. Dengan demikian dilakukanlah kegiatan pengabdian kepada masyarakat oleh mahasiswa KKN PPM Universitas Muhammadiyah Pontianak tahun 2018 yang membantu memberdayaan masyarakat melalui kegiatan rumah pintar demi menuntaskan masalah ketertinggalan pendidikan pada anak- anak serta memberantas buta aksara pada masyatrakat di Desa Sungai Mawang (Sudjana, 2004)

\section{MASALAH}

Berdasarkan analisisi situasi dapat diidentifikasi permasalahan yang dihadapi masyarakat Desa Sungai Mawang dalam menuntaskan masalah ketertinggalan pendidikan yaitu:

1. Keterbatasan sarana belajar bagi anak- anak, baik yang formal maupun informal

2. Kurangnya pemahaman masyarakat tentang pentingnya pendidikan 
3. Rendahnya kepedulian masyarakat akan pendidikan anak

Berdasarkan permasalahan tersebut maka perlu adanya sarana pendidikan yang dapat mengedukasi masyarakat tentang pentingnya pendidikan dan sebagai sarana belajar anak- anak serta masyarakat yang buta aksara melalui pemberdayaan masyarakat dengan membangun rumah pintar di Desa Sungai Mawang.

\section{METODE PELAKSANAAN}

Metode pelaksanaan kegiatan rumah pintar ini, kami lakukan dengan beberapa tahapan yaitu: persiapan, pelaksanaan dan evaluasi.

\section{Persiapan}

Tahap persiapan ini dilakukan dengan penjajakan atau soaialisasi kepada masyarakat serta siswa- siswi di PAUD dan Sekolah Dasar yang ada di Desa Sungai Mawang mengenai pentingnya pendidikan, dan membaca buku. Serta mempromosikan keberadaan dan kegiatan yang ada di rumah rumah pintar Desa Sungai Mawang. Metode yang digunakan dalam melakukan pemberdayaan kelompok sasaran ini adalah partisipatif dan dialogis.

\section{Pelaksanan}

Pelaksanaan kegiatan rumah pintar ini dilakukan dengan beberapa metode pembelajaran yang berbeda untuk menarik minat belajar siswa serta ketertarikan siswa dalam membaca. Kegiatan ini dilakukan dengan pemberian beberapa materi pelajaran mulai dari tingkatan pendidikan anak usiia dini (PAUD) hingga Sekolah Dasar. Kegiatan pembelajaran yang dilakukan meliputi mata pelajaran matematika, IPA, sejarah, kesenian serta kegiatan belajar sambil bermain yang menyenangkan.

\section{Evaluasi}

Evaluasi terhadap pelaksanaan kegiatan ini dilakukan baik dalam proses pembelajaran maupun hasil yang didasarkan pada beberapa aspek, yaitu: kehadiran peserta, keaktifan peserta dan hasil belajar siswa.

\section{HASIL DAN PEMBAHASAN}

\section{Inisiasi rumah pintar}

Rumah pintar yang merupakan sarana belajar anak- anak Desa Sungai Mawang didirikan oleh mahasiswa KKN-PPM Universitas Muhammadiyah Pontianak 2018 bersama para pemuda Desa Sungai Mawang. Tujuan dilakukannya inisiasi rumah pintar ini yaitu sebagai sarana belajar bagi anak- anak di Desa Sungai Mawang serta orang tua yang 
ingin menambah ilmu pengetahuannya serta untuk dapat meningkatkan minat baca siswa dan memperbaiki wawasan anak- anak dalam mengenal huruf dan membaca. Sebab berdasarkan hasil observasi temuan di lapangan yang dilakukan di SDN 24 Desa Sungai Mawang menunjukkan bahwa rata- rata siswa di SDN 24 Desa Sungai Mawang mulai dari kelas 1-3 belum dapat membaca. Dengan begitu adanya rumah pintar ini diharapkan dapat membantu anak- anak di Desa Sungai Mawang dalam belajar membaca serta memberantas buta aksara.
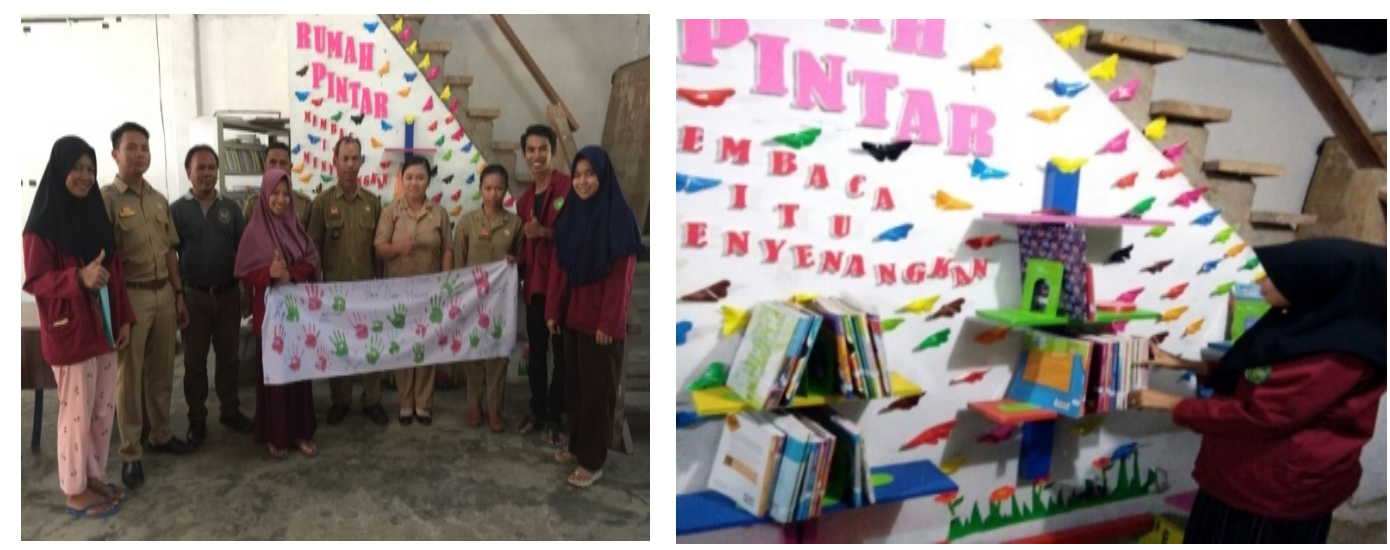

Gambar 1. Kegiatan inisiasi rumah pintar

Menurut ibu Darminten salah satu guru SDN 24 Sungai Mawang, berdirinya rumah pintar memberikan dampak positif bagi anak- anak di Desa Sungai Mawang mulai dari Dusun Mawang, Dusun Sanjan serta Dusun Nyandang. Hal ini dikarenakan di Desa Sungai Mawang ini pendidikan anak usia dini (PAUD) baru dibuka pada pertengahan Juli 2018 sehingga sebagian besar siswa yang menempuh pendidikan SD (sekolah Dasar) belum sama sekali mengenyam bangku pendidikan PAUD yang seharusnya mereka dapatkan. Sehingga sebagai guru ibu Darminten merasa cukup kesulitan karna harus mendidik mereka dari awal atau dapat dikatakan dari 0 (nol). Dengan demikian, dengan adanya rumah pintar ini para guru SDN 24 Sungai Mawang ini sangat menyambut positif dan menyarankan bagi siswa- siswinya untuk dapat belajar di rumah pintar.

Respon serta antusias anak- anak di Desa Sungai Mawang dengan adanya rumah pintar ini sangat baik. Hal ini dapat dilihat dari semangat mereka yang sangat luar biasa. Ketika cuaca hujan siswa masih saja semangat untuk datang belajar dan bertemu dengan teman- temannya. Dengan demikian kegiatan dan pengeloaan rumah pintar harus dapat dijalankan dengan baik, untuk memfasilitasi siswa yang memiliki semangat belajar tinggi 
agar memiliki pengetahuan yang lebih maju dari sebelumnya. Inisiasi rumah pintar ini dilakukan mulai hari Selasa 31 Juli 2018 hingga Minggu 12 Agustus 2018. Sebelum dilakukan proses inisiasi rumah pintar ini, penulis selaku penanggung jawab program telah berkoordinasi dengan pihak desa terutama kepala desa untuk menentukan lokasi yang tepat dan strategis untuk membangun rumah pintar. Berdasarkan rekomendasi yang diberikan, lokasi yang dijadikan tempat dibangunnya rumah pintar yaitu Balai Dusun Sungai Mawang. Lokasi ini dipilih dengan alasan bahwa kantor Desa Sungai Mawang sedang dalam masa perbaikan atau renovasi sehingga perputakaan desa yang ada di kantor desa lokasinya pun juga dipindahkan ke Balai Dusun Sungai Mawang serta untuk lokasi lainnya sudah memiliki fungsinya masing- masing. Dengan demikian lokasi rumah pintar bergabung dengan perpustakaan desa di Balai Dusun Sungai Mawang.

Bergabungnya lokasi rumah pintar dan perpustakaan desa ini membuat koleksi buku- buku yang ada di Desa Sungai Mawang ini semakin lengkap. Berdasarkan hasil wawancara yang penulis lakukan kepada Kepala Desa, perpustakaan desa ini baru ada sejak tahun 2016 dari bantuan BPKD Provinsi Kalimantan Barat. Dan perpustakaan ini belum berfungsi secara optimal, sebab hanya dilakukan pendataan buku tanpa ada tindak lanjutnya atau dapat dikatakan Vakum dari segala bentuk kegiatan. Dengan adanya rumah pintar ini perpustakaan desa tentunya dapat lebih berkembang dengan kader yang tentunya memiliki rasa tanggung jawab tinggi untuk mengelola rumah pintar tersebut.

\section{Kader Rumah Pintar}

Kegiatan pelatihan kader rumah pintar juga merupakan agenda penting dalam keberlanjutan program rumah pintar. Program pelatihan kader rumah pintar dilakukan pada hari Senin, 27 Agustus 2018. Pelatihan kader ini dilakukan untuk memberikan pemahaman, pengetahuan serta keterampilan bagi kader dalam mengelola rumah pintar Desa Sungai Mawang. Pelatihan kader Rumah pintar Desa Sungai Mawang dilakukan dengan mengikut sertakan kader dalam berbagai kegiatan rumah pintar misalnya dalam kegiatan pembelajaran rumah pintar serta inventaris buku sebagai bentuk praktek langsung di lapangan. Hal inilah yang merupakan tugas dasar kader rumah pintar.

Kader rumah pintar berjumlah 1 orang yang merupakan anak muda dari Desa Sungai Mawang. Kader ini dipilih dan ditunjuk langsung oleh kepala Desa Sungai Mawang bapak Hironimus. Marsiana Sely merupakan staf desa yang mengurusi bidang perpustakaan desa yang diangkat pada tanggal 13 Juni 2018 berdasarkan Surat Keputusan Kepala Desa Sungai Mawang No. 19 Tahun 2018 Tentang Pengelola Perpustakaan Desa Sungai 
Mawang. Dengan begitu beliau dapat bersama-sama berkolaborasi dalam menjalankan kedua tugas yang kedua-duanya memiliki hubungan yang erat. Dengan begitu dapat lebih mudah dalam pelaksanaannya dengan dasar pengetahuan dan pengalaman tentang pengelolaan buku bacaan yang sudah ada.

\section{Kegiatan Rumah Pintar}
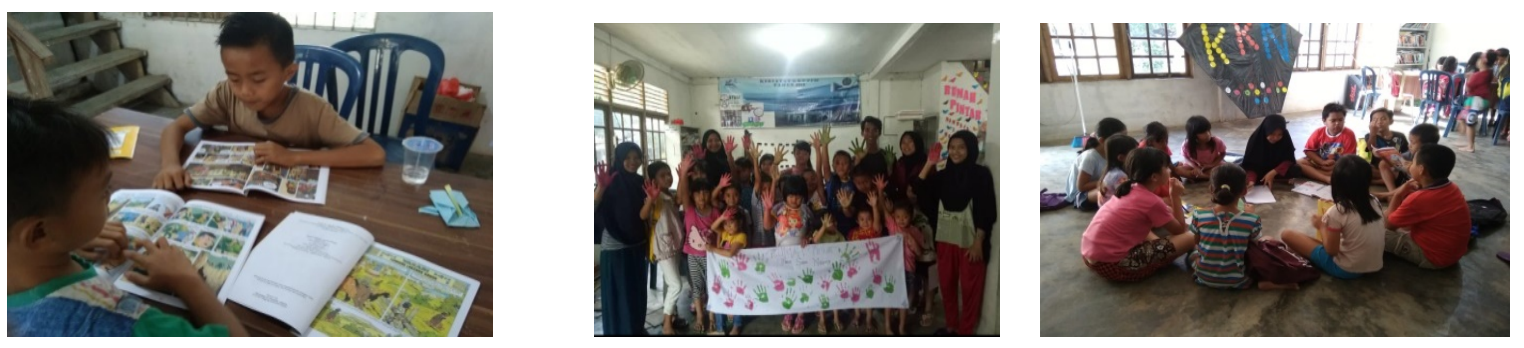

Gambar 2. Gambar 2 Kegiatan Rumah Pintar

Hadirnya rumah pintar sebagai salah satu upaya pemberdayaan masyarakat di sektor pendidikan sangatlah penting. Paling tidak dapat memberikan kesempatan pada masyarakat yang tidak tersentuh oleh pendidikan formal untuk dapat merasakan pendidikan di rumah pintar ini. Selain orang tua, sasaran utama berdirinya rumah pintar ini yaitu anak- anak. Rumah pintar bagi anak- anak berguna untuk memberikan pendidikan dasar sebelum memasuki dunia sekolah atau sebagai tempat belajar sambil bermain.

Sistem penyelenggaraan rumah pintar mengacu pada kondisi, situasi dan kemampuan masyarakat di Desa tersebut dengan tetap berorientasi pada pemberdayaan masyarakat agar masyarakat khususnya anak-anak bisa belajar, menambah pengalaman dan keterampilan yang akan berguna bagi kehidupannya sesuai dengan tujuan berdirinya rumah pintar. Kegiatan yang dihadirkan dalam rumah pintar ini disesuaikan dengan kebutuhan belajar siswanya. Namun pada beberapa kondisi siswa diajak belajar bersama tanpa memilihat jenjang pendidikan yang sudah mereka jalani. Kegiatan tersebut seperti bermain ular naga panjang yang didalamnya disisipi pertanyaaan- pertanyaan seputar pelajaran sekolah seperti Matematika ataupun sains. Agenda kegiatan pembelajaran di rumah pintar dilaksanakan secara rutin setiap hari senin dan rabu dari pukul 14.30-16.00 WIB dan dimulai tanggal 06 Agustus 2018. Jumlah siswa yang hadir dalam kegiatan ini yaitu 45 orang anak.

Kegiatan rutin pembelajaran di rumah pintar dilakukan secara terjadwal namun apabila ada permintaan anak- anak untuk belajar mata pelajaran tertentu, maka kami 
sesuaikan dengan yang menjadi kebutuhan anak- anak. kegiatan yang kami berikan berupa pembelajaran dasar seperti belajar menulis, membaca, menghitung, mewarnai, membuat kolase dengan berbagai bahan, belajar menulis dan membaca bahasa inggris, belajar ilmu pengetahuan alam tingkat sekolah dasar, belajar seni melipat kertas, pengukuran status gizi secara berkala dan berbagai pembelajaran sederhana lainnya. Kegiatan rutin yang dilakukan dalam rumah pintar ini mengajarkan anak- anak dari yang awalnya mewarnai masih melewati garis, namun dengan sungairing waktu anak- anak semakin pandai mewarnai sesuai pola gambar yang ada. Dari yang belum lancar membaca menjadi lebih lancar membacanya, dari yang masih malu- malu jika diperintahkan maju menghafalkan bahasa inggris hingga mereka terbiasa maju menyampaikan hafalan bahasa inggris mereka. perubahan-perubahan sederhana inilah yang mungkin tidak disadari anak- anak merupakan hasil dari perkembangan belajar mereka yang tentunya menunjukkan hal yang lebih baik.

\section{Inventaris Buku}
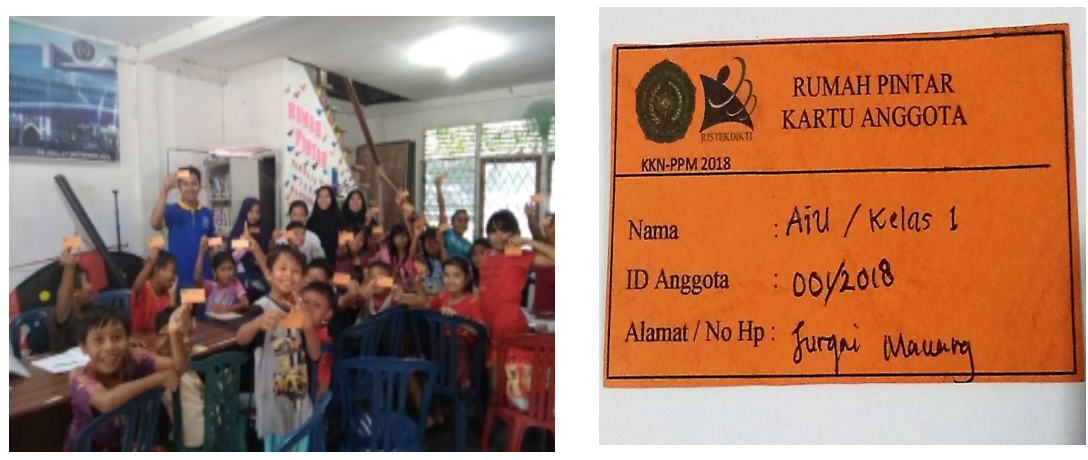

Gambar 3. Kegiatan Inventaris buku

Setelah berjalannya kegiatan rumah pintar ini dengan sasaran anak-anak SD dan PAUD banyak mendapatkan respon positif dari masyarakat ataupun dari orang tua anakanak. Dengan adanya rumah pintar mempermudah anak-anak untuk belajar apa yang belum mereka ketahui, dan mengajarkan anak-anak tentang hal-hal yang baru. Selain itu rumah pintar ini dibangun dengan design yang dibuat semenarik mungkin sehingga membuat anak-anak merasa nyaman, senang, dan bisa betah belama-lama belajar dirumah pintar. Demi keberlangsungan pengelolaan rumah pintar, kader menyiapkan beberapa hal mengenai administrasi rumah pintar. Seperti kartu peminjaman buku, lebel kode buku, jurnal peminjaman buku yang tentunya dibuat untuk mempermudah kader dalam mengelola atau mendata buku- buku yang ada di rumah pintar. Pendataan ini dilaksanakan 
pada hari Sabtu 25 Agustus 2018. Selain itu dalam pembelajaran, kader juga menyediakan raport mini yang menerangkan mengenai tumbuh kembang anak selama mengikuti kegiatan pembelajaran di rumah pintar Desa Sungai Mawang.

\section{KESIMPULAN}

Upaya pengembangan pendidikan anak di desa Sungai Mawang melalui kegiatan rumah pintar berjalan sesuai harapan dengan antusias anak- anak yang luar biasa. Perkembangan yang diterima anak-anak melalui kegiatan rumah pintar Desa Sungai Mawang ini meliputi perubahan anak- anak dari yang awalnya mewarnai masih melewati garis, namun dengan sungairing waktu anak- anak semakin pandai mewarnai sesuai pola gambar yang ada. Dari yang belum lancar membaca menjadi lebih lancar membacanya, dari yang masih malu- malu jika diperintahkan maju menghafalkan bahasa inggris hingga mereka terbiasa maju menyampaikan hafalan bahasa inggris mereka, serta berbagai perubahan lainnya yang menunjukkan perkembangan belajar menuju arah yang lebih baik. Perubahan yang baik ini membuat anak- anak yang lain semakin termotivasi untuk terus belajar dan belajar.

\section{UCAPAN TERIMA KASIH}

Penelitian ini dapat selesai dengan baik karena bantuan dari berbagai pihak. Oleh karena itu penulis mengucapkan terimakasih kepada kepala Desa Sungai Mawang atas izin yang diberikan kepada penulis untuk melaksanakan pengabdian di Desa Sungai Mawang, kepala sekolah SDN 24 Sungai Mawang serta rekan- rekan guru yang telah banyak membantu demi kelancaran kegiatan rumah pintar. Dan tak lupa pula saya ucapkan banyak terima kasih kepada Kemenristek Dikti, Rektor Universitas Muhammadiyah Pontianak, Dosen Pembimbing Lapangan serta Tim KKN-PPM Universitas Muhammadiyah Pontianak yang telah banyak mensupport kegiatan pengabdian di Desa Sungai Mawang hingga selesai.

\section{DAFTAR PUSTAKA}

Amirullah, G., \& Susilo, S. (2018). Pengembangan Media Pembelajaran Interaktif Pada Konsep Monera Berbasis Smartphone Android. WACANA AKADEMIKA: Majalah Ilmiah Kependidikan, 2(1), 38-47.

Badan Pusat Statistik. (2017). Kabupaten Sanggau Dalam Angka 2017. kaimantan barat.

Hasiani, F. (2015). Analisis Kualitas Sumber Daya Manusia Dan Pengaruhnya Terhadap Pertumbuhan Ekonomi Di Kabupaten Pelalawan. Jom FEKON 2. 
Kartadinata, S. (2007). Pendidikan dan Pengembangan SDM Bermutu Memasuki Abad XXI. Purwokerto: Makalah Konvensi.

Khan, R. imani dan N. Y. (2016). Meningkatkan Kemampuan Berhitung Anak Usia Dini Melalui Permainan Bowling Kaleng. Universum 10.

Sudjana, S. H. (2004). Manajemen program pendidikan, untuk pendidikan nonformal, dan pengembangan sumber daya manusia. Bandung: Falah Production.

Sulastri, S., Akbar, B., Safahi, L., \& Susilo, S. (2018). Pengaruh Strategi Pembelajaran Critical Incident terhadap Keterampilan Analisis Siswa (The Effect of Critical Incident Learning Strategy on Students' Analytical Skills). Assimilation: Indonesian Journal of Biology Education, 1(2), 77-81. Retrieved from http://ejournal.upi.edu/index.php/asimilasi/article/view/13051

Syintia, S., Akbar, B., Safahi, L., \& Susilo, S. (2018). Pengaruh Strategi Pembelajaran Relating, Experiencing, Applying, Cooperating, Transferring (REACT) terhadap Keterampilan Proses Sains Siswa. Assimilation: Indonesian Journal of Biology Education, 1(2), 82-85. Retrieved from http://ejournal.upi.edu/index.php/asimilasi

UNDP. (2016). Human Development Report 2016 Human Development for Everyone. united.

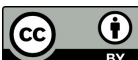

(C) 2019 Oleh authors. Lisensi Jurnal Solma, LPPM-Uhamka, Jakarta. Artikel ini bersifat open access yang didistribusikan di bawah syarat dan ketentuan Creative Commons Attribution (CC BY) license. (http://creativecommons.org/licenses/by/4.0/). 